\title{
AKRUAL
}

Jurnal Akuntansi

http://journal.unesa.ac.id/php.index/aj

\section{Factors that Affect Academic Achievement Student}

\author{
Kurniasari Novi Hardanti \\ Universitas Internasional Semen Indonesia \\ kurniasari.hardanti@uisi.ac.id
}

\begin{abstract}
The aim of this research is to reveal the influence of student's background when entered university are the entrance, the priority option to choose field of study, majoring of the high school, mathematics value in high school, and other factor is active to follow assistance toward academic achievement accounting student, that explain as value quantitative accounting and Grade Point Advantage. The population of the research is undergraduate students of the Department of Accounting, Faculty of Economy and Business, University of Brawijaya, entering in 2008, still enlisted as active student, and is having auditing practice course. The data of the research is taken by using questionnaire. The questionnaires given are 170 but only 137 which meet the criteria purposive sampling. Result of the research show that only university recruitment's way and active to follow assistance that has significant influence on the academic achievement for Accounting Student.
\end{abstract}

Keywords: Academic achievement in quantitative accounting, active assistance, Grade Point Advantage, majoring of the high school, mathematics value in high school, the entrance, the priority option to choose field of study.

\section{INTRODUCTION}

Education is an activity that is always aware of the purpose. One goal of education is to get the human resources quality. To obtain quality human resources can be done through teaching and learning activities. Teaching and learning activities greatly affect the outcome of an educational system [1]. Teaching and learning activities held from level to start from elementary school up to college. The role of universities is becoming increasingly important to deal with increasing competition. Number of jobs that are not comparable with the number of graduates each year requires an active role in the printing college graduates who are competent in their field, so ready to compete to meet the needs of the workforce. Therefore, universities should make the preparation of selection into college better assess students' abilities rather than his knowledge at the time of entrance examination. Therefore, the preparation of the purpose of education is not only important, but it is a necessity [2]. Brawijaya University (UB) currently occupies the position of the 13 best universities in Indonesia [3]. In order to maintain the reputation and meet the demands of the working world, UB has a vision to become the leading universities of 
international standard and be able to play an active role in nation building through education, research and community service.

\section{HYPOTHESIS DEVELOPMENT}

\section{The Entrance (X1)}

This variable is actually a proxy of intelligence of students who can be seen from the rigor of competition are reflected from the entrance of each driveway. The entry point for the 2008 class can be classified into five, namely SNMPTN, SpMK, PSB Academic, SPKS, SPKIns. According [4] this intelligence is one of the factors that influence learning achievement. The achievement of quantitative accounting courses are core courses achievement of accounting which is a subject that is closely connected with the matter. In addition to the quantitative achievements of course, also will affect the GPA. Good and poor performance can be influenced by the level of intellect that can be measured from the entrance admissions. Based on this theory, a hypothesis can be formulated: Trail entrance effect on the achievement of students studying accounting.

\section{The Priority Option (X2)}

Priority options when the selection is actually a proxy of student interest and motivation to enter the accounting department. Given the interest and motivation in the early entry, students will be more motivated to excel. There are three priority levels, including the first choice, second, and third. Previous research found that the variable interest in majors and motivation to learn a positive effect on learning achievement variables. In contrast, research conducted by [5] who found that student achievement a priority choice for the Accounting Department of Economics and Business Faculty of 2007 UB in the subject of quantitative accounting showed no significant results. Therefore, hypothesis 2 is the priority choice affecs the achievement of students studying accounting.

\section{Majoring at The High School (X3)}

Programs at the high school and is a proxy of the equal amount of knowledge of the students of accounting at the college level before. With a wealth of experience in accounting at the level of previous education will help in achieving good performance in accounting courses. The department consists of three, namely Social Studies, Science and Languages. Research in [5] which revealed that the accounting / bookkeeping obtained in high school will positively affect student achievement in higher education in basic 
accounting. Agree with [6], [7] found a number of accounting experience in high school will support the achievement of students of accounting courses in the initial stages only. Based on this theoretical basis the proposed hypothesis 3: Department of SMA affect the achievement of students studying accounting.

\section{The Mathemathics Value in High School (X4)}

Accounting majors are the majors with core courses with numbers and calculations are quite complicated. With good mathemathic scores, the ability of the student count is good and ultimately impact on the achievement of quantitative courses are a good accounting. This variable is measured by looking at the average value of math in high school. Based on this theoretical basis the fourth hypothesis is proposed: Mathematics Achievement in high school affect student achievement accounting.

\section{Active to Follow assistance program (X5)}

Activity in the assistance program is a proxy of preparation and study habits. Assistance programs conducted outside of class hours in general can help student understanding. This variable is measured by student participation in class, the arrival routine, and an understanding of the material provided by the relevant teaching assistant [8]. The program is carried out effective day of classes in general. Assistance programs administered by the teaching assistant is what attracted me to better understand the relationship between activity in the student assistance program to the achievement of quantitative accounting-related subjects. Not all quantitative courses have a teaching assistant. Based on this theoretical basis it is proposed hypothesis 5: the active assistance following the effect on student learning achievement of accounting.

\section{METHODS}

\section{Population and Sample}

The population in this study were all students of the Faculty of Accounting Department of Economics and Business class 2008 who is doing his practicum course auditing. This is because this research has the dependent variable is quantitative accounting course performance and GPA. Students who are taking practical auditing courses are assumed to have passed the quantitative accounting. As for all the students who were taking Auditing Practicum was 201 people, while, class 2008 who is doing his practicum Auditing is 170 people (attendance Organization Accounting Assistant Lecturer). 


\section{Data Collection Techniques}

Data collection technique used was a questionnaire. Questionnaires are a number of written questions used to obtain information from respondents in terms of statements about personal.

\section{Variables}

Dependent variable (Y) in this fieldwork was the subject of quantitative accounting (Y1) of the Department of Accounting Faculty of Economics and Business UB force in 2008. Size values are classified as follows: $\mathrm{A}=$ excellent, $\mathrm{B}=\operatorname{good}, \mathrm{C}=$ adequate, $\mathrm{D}=$ less, $\mathrm{E}=$ ugly. The second dependent variable (Y2) is the GPA. GPA is grade point average is used as the basis for determining the predicate completion.

The independent variable is a variable that affects the variation of other variables. The independent variable in this study are the factors that influence the achievement of quantitative accounting courses and GPA. The independent variable in this study are 5, the entry point, the priority during the selection choices, majors in high school, majoring in high school, high school math achievement, and the activity of the assistance program.

\section{Data Analysis Methods}

Testing of research hypotheses is done using multiple linear regression analysis. Multiple linear regression is used to determine the pattern of relationships between more than one independent variable (X1, X2, X3, X4, X5) with two dependent variables (Y1, Y2). Of multiple linear regression equation used in this study are as follows:

$$
\begin{aligned}
& Y_{1}=a+b_{1} X_{1}+b_{2} X_{2}+b_{3} X_{3}+b_{4} X_{4}+b_{5} X_{5}+e \\
& Y_{2}=a+b_{1} X_{1}+b_{2} X_{2}+b_{3} X_{3}+b_{4} X_{4}+b_{5} X_{5}+e
\end{aligned}
$$

\section{Description:}

Y1=Achievement quantitative study subjects Accounting

$\mathrm{Y} 2=\mathrm{GPA}$

$\mathrm{a}=$ constant (intercept)

$\mathrm{X}_{1}=$ The entrance

$\mathrm{X}_{2}=$ The priority option

$\mathrm{X}_{3}=$ Majoring at The High School

$X_{4}=$ The Mathemathics Value in High School

$\mathrm{X}_{5}=$ Active to Follow assistance program

b1-b5 = coefficient of regression

$\mathrm{e}=$ Error nuisance (standard error) 
Before performing data analysis using multiple regression analysis, this is done to understand whether the data meets the assumptions of classical or not. Classical assumption in this study include tests of normality, is tested using the Kolmogorov Smirnov, multicollinearity tests, were tested by using the values of tolerance and variance inflation factor, and heteroscedasticity tests are tested using the Glejser Test.

\section{RESULT AND DISCUSSION}

\section{Descriptive Statistics}

Data on the driveway, priority selection, majors high school or equivalent, math achievement, active assistance program, the value of accounting courses, and GPA were collected through a questionnaire. Questionnaires distributed 170 pieces numbered according to the total number of students who are taking courses to seven classes auditing practice that there is a class $\mathrm{CA}, \mathrm{CB}, \mathrm{CC}, \mathrm{CD}, \mathrm{CE}, \mathrm{CF}$ and $\mathrm{CG}$. After collection, the questionnaires are returned and in accordance with the criteria for purposive sampling of 137 questionnaires were numbered. The criteria for purposive sampling in this study were students of 2008 who is doing his practicum, and graduated from high school in 2008. The results of descriptive statistical analysis performed using SPSS 15 shows that the percentage of students who were respondents in this study were $64.23 \%$ and $35.77 \%$ are students. The results of descriptive statistical analysis conducted in the respondents indicated that there are five pathways taken by students, namely SNMPTN, academic PSB, SpMK, SPKS, and SPKIns. Largest contributor in research is a pathway that is equal to 54\% SNMPTN, followed SpMK 21.9\% and 19.7\% PSB Academic later SPKS SPKIns $2.9 \%$ and $1.5 \%$. From the results of this descriptive analysis, it can be concluded that the main entry point is from SNMPTN which accounts for more than 50\% the number of students. Below is a table of descriptive statistics of the path of admission:

Table 4.1

\section{Frequency distribution Entrance Paths}

\begin{tabular}{lcc}
\hline \multicolumn{1}{c}{ Sign pathway } & Frequency & Percentage (\%) \\
\hline SPKIns & 2 & 1,5 \\
SPKS & 4 & 2,9 \\
SPMK & 30 & 21,9 \\
PSB Akademik & 27 & 19,7 \\
SNMPTN & 74 & 54 \\
Total & 137 & 100,00 \\
\hline
\end{tabular}


For priority selection found that the majority of respondents (85.4\%) in this study chose the Accounting Department as its first choice. After that the respondents followed by $13.14 \%$ for the second choice and third choice, namely $1.46 \%$. Below is a table of descriptive statistics of priority options:

Table 4.2

Frequency distribution of Priority Options

\begin{tabular}{lcc}
\hline \multicolumn{1}{c}{ Priority } & Frequency & Percentage (\%) \\
\hline Priority 3 & 2 & 1,46 \\
Priority 2 & 18 & 13,14 \\
Priority $\mathbf{1}$ & 117 & 85,40 \\
Total & 137 & 100,00
\end{tabular}

In connection with a major in high school or equivalent, the majority of the student's home department is the IPS, amounting to $52.55 \%$ which beat the percentage of science majors in the amount of $42.34 \%$. This is in line with the concept that accounting is a branch of the relevant social science intended for students majoring in social as well. In addition, also found the seven respondents who originated from the Department of Languages. Below is a table of descriptive statistics from high school or equivalent majors:

Table 4.3

Frequency distribution of high school subjects

\begin{tabular}{lcc}
\hline \multicolumn{1}{c}{ Subject } & Frequency & Percentage (\%) \\
\hline Language & 7 & 5,11 \\
IPA & 58 & 42,34 \\
IPS & 72 & 52,55 \\
Total & 137 & 100,00 \\
\hline
\end{tabular}

In relation to the value of mathematics, the majority of respondents had math scores between 80 and 100 in high school that as many as 95 people (69.3\%). A total of 35 people $(25.55 \%)$ had math scores between 70 and 79 , and as many as seven people (5.1\%) had math scores between 60 and 69. Below is a table of descriptive statistics of the value of math in high school: 
Table 4.4

Frequency distribution of Mathematics Value

\begin{tabular}{lcc}
\hline \multicolumn{1}{c}{ Value of Mathematics } & Frequency & Percentage (\%) \\
\hline $\mathbf{6 0}-\mathbf{6 9}$ & 7 & 5,11 \\
$\mathbf{7 0}-\mathbf{7 9}$ & 35 & 25,55 \\
$\mathbf{8 0}-\mathbf{1 0 0}$ & 95 & 69,34 \\
Total & 137 & 100,00 \\
\hline
\end{tabular}

\section{Classical Test Assumptions}

Testing the validity of the instrument was done by using Pearson Product Moment correlation. The instrument can be said to be valid if the value of Pearson Correlation> 0.5 . From the test, show that all statements in the questionnaire had to meet the validity test for the Pearson Correlation showed $>0.5$ and a significance $<0.05$.

Reliability testing of the questionnaire carried out using Cronbach Alpha. A questionnaire study dikalatakan reliable if the Cronbach alpha coefficient over 0.6. The obtained Cronbach's alpha coefficient of 0.859 , where the coefficient is more than 0.6. So it can be concluded that the questionnaire used in this study have been reliable.

\section{Classical Assumptions Testing Results}

Based on the Kolmogorov-Smirnov test above, the dependent variable values for Accounting Courses (Y1) yield coefficient of 0.686 Kolmogorov-Smirnov test with a significance value $>0.05$ is equal to 0.734 . Based on these results we can conclude that the regression model used to model Value Accounting Courses (Y1) has met the normality assumption.

In the second regression model with the dependent variable GPA (Y2) obtained coefficients of 0.621 Kolmogorov-Smirnov test with a significance value $>0.05$ is equal to 0.835 . Because the significance value is greater than $\alpha=0.05$, we can conclude the model GPA (Y2) has met the normality assumption.

Heteroscedasticity test aims to test whether the regression model of the residual variance inequality occurred one observation to another observation. If the residual variance from one observation to another observation remains, it is called and if different homoskedastisitas called heteroscedasticity. A good regression model is a model homoskedastisitas or non-occurrence of heteroscedasticity. One method used to test whether or not there is a test Glejser heteroscedasticity. Glejser test conducted by 
meregresikan between independent variables used in the study with the absolute value of residual. Regression model is said to occur if the heteroscedasticity in each of the independent variables do not form a significant influence with the absolute residuals.

Based on the testing table Glejser heteroscedasticity by using the test, can be explained that in the second regression model, each independent variable has no significant effect on the absolute residuals. Thus, from these tests can be concluded that the regression model is formed does not possess heteroscedasticity.

\section{Hypothesis Testing Results}

\section{Testing the Model Using Value}

Hypothesis testing is done by multiple linear regression test at a significance level $\alpha=5 \%$ using SPSS 15. The results of hypothesis testing on the model values are listed in Table 4.5

Table 4.5

Test Result Hypothesis Model Y1 (Score)

\begin{tabular}{ccccc}
\hline Variables & t-test & Description & F-test \\
\cline { 2 - 2 } & Sig & & Sig \\
(Constant) & 0,000 & & Significant & 0,000 \\
X1 & 0,002 & & Significant & \\
X2 & 0,655 & Not Significant & \\
X3 & 0,001 & Significant & \\
X4 & 0,023 & Significant & \\
X5 & 0,000 & Significant & \\
\hline
\end{tabular}

\section{Testing the Model Using the CPI}

Hypothesis testing is done by multiple linear regression test at a significance level $\alpha=5 \%$ using SPSS 15 . The results of hypothesis testing in models of GPA can be seen in Table 4.6 
Table 4.6

Test Result Hypothesis Model Y2 (GPA)

\begin{tabular}{|c|c|c|c|}
\hline Variabel & t-test & Description & F-test \\
\hline & Sig & & Sig \\
\hline (Constant) & 18,683 & Significant & 0,000 \\
\hline $\mathbf{X 1}$ & 3,929 & Significant & \\
\hline $\mathbf{X} 2$ & 0,821 & Not Significant & \\
\hline $\mathbf{X 3}$ & 0,901 & Not Significant & \\
\hline $\mathbf{X 4}$ & 1,140 & Not Significant & \\
\hline X5 & 7,423 & Significant & \\
\hline
\end{tabular}

\section{CONCLUSION}

This study shows that there is a positive influence of the entrance to the achievement of students studying accounting proxy by the value of quantitative accounting courses and GPA. These results indicate that the empirical evidence of a pathway which is a proxy of the level of intelligence to support student learning achievement of students both proxy with the accounting courses as well as the GPA. High level of intelligence that can make individuals easier to think rationally and the results can be maximized.

This study shows that the priority option has no effect on student learning achievement proxy by accounting with value accounting and quantitative courses GPA. These results indicate that the priority of selection is not an appropriate proxy of interest. Priority in filling students do not always fill it on her own but, encouraged by parents and friends. These results are consistent with the findings made by [5] who said that priority option has no effect on the value of quantitative accounting courses. Thir result is most likely caused by a proxy who is not quite right.

This study shows that there is no positive effect among the majors in high school on student learning achievement proxy by accounting with the accounting courses and GPA. Majors in high school only has a positive impact on the accounting subjects only, whereas no effect on GPA. The results are consistent with other studies conducted [9] and [10] who found that exposure of accounting at secondary school level have no connection with the performance or student achievement.

This study shows that there is no positive effect of math grades in high school or equivalent of accounting student learning achievement proxy by with the accounting courses and GPA. Math scores in high school only has a positive impact on the 
accounting subjects only, whereas no effect on GPA. In order to have a high GPA, required intellectual abilities, interests, talents, and exposure to accounting. Of understanding that exist in the academic handbook 2008/2009 is, it is understood that the GPA does not only consist of basic courses that require a count, but also on other sciences that are memorized and understood.

This study shows that there are positive effects of active assistance to the achievement of students studying accounting proxy by quantitative value accounting courses and GPA. These results indicate that the active assistance of empirical evidence which is a proxy of student study habits can support both student learning achievement proxy by with the accounting courses and the GPA. Although not all accounting courses have assistance programs outside of the actual course, it remains active assistance has a significant effect on GPA. This is in line with the rationalization when a student can actively pursue assistance program carried out at the course, the student will easily be actively attending the effective day as usual. Results of this study are also consistent with research by [8] who found that student achievement will increase with the presence of each individual.

This study aims to determine the significance of the influence of background of students entering college, which is the entrance, priority selection, majors, math grades in high school or equivalent, as well as active assistance program on student learning achievement of Accounting Department of Economics and Business Faculty of the UB force 2008 which proxy to accounting courses and overall GPA either partially or simultaneously. This study uses multiple linear regression analysis. This study found a significant effect between the entrance and follow the activity of assistance to the achievement of students studying accounting. This study has limitations, namely the use of a limited number of samples. In addition, the selection of independent variables is quite a bit and have not been able to cover the whole. Based on the above limitations, the researcher is further recommended to undertake neat research with the wider population or with other variables are concerned about the possibility of student background affects student achievement both in the scope of the achievement of specific or more general. 


\section{References}

Baldwin, BA dan K.R Howe. 1982. Secondary-Level Study of Accounting and Subsequent Performance in First College. The Accounting Review, Juli pp-616-626

Bergin, J.L. 1983. Teaching Introductory Financial Accounting in Mass Lecture System: Logitudinal Evidence. Issues in Accounting Education. 8 (1): 97-111

Harahap, Ridoni Fardeni. 2011. Pengaruh Jalur Masuk, Prioritas Pilihan pada Saat Seleksi Penerimaan Mahasiswa Baru, dan Jurusan Di Sekolah Menengah Atas terhadap Prestasi Mata Kuliah Kuantitatif Akuntansi. Skripsi. Universitas Brawijaya. Malang.

Islami, Nadu Azizah. 2009. Pengaruh Persepsi Siswa Mengenai Media Pembelajaran Guru dan Keaktifan Siswa dalam Proses Pembelajaran. Surakarta. Skripsi. Universitas Muhammadiyah. Surakarta.

Keef, S. P. (1988). Preparation for first level university accounting course: The experience in New Zealand. Journal of Accounting Education, 6(2), 293-307.

Rooijakkers, Ad. 1986. Mengajar dengan Sukses Petunjuk untuk Merencanakan dan Menyampaikan Pengajaran. Jakarta: PT Gramedia

Slameto. 2003. Belajar dan Faktor-faktor yang Mempengaruhinya. Jakarta: Rineka Cipta

Smith, C. G. (1991). Determinants of Student Performance in Accounting Principles I and II. Issues in Accounting Education, 6(1), 74-84.

Utomo, Tjipto dan Kees Riujter. 1985. Peningkatan dan Pengembangan Pendidikan. Jakarta: PT Gramedia

www.4icu.org. Date access 3 Oktober 2011. University rank based on website. 